\title{
OVERLOOKING THE OBVIOUS: THE OPPORTUNITY FOR HERBICIDES IN AFRICA
}

\author{
Leonard Gianessi and Ashley Williams of the CropLife Foundation, Washington, DC, USA argue that poorly \\ controlled weeds are the biggest constraint to improving crop production in Africa
}

Keywords: Africa, development, weeds, herbicides, crop yields

Twenty years ago, the International Institute of Tropical Agriculture's Dr. I. Okezie Akobundu clarified the gap between crop yields on research farms in sub-Saharan Africa and those on smallholder farms - weeds (Akobundu 1991). Today, farmers in Africa continue to realize $70 \%$ lower yields than researchers on weeded plots. Reasons for the lag include weeding at suboptimal times and labor constraints. Most significantly, $90 \%$ of acres on large plantation farms in subSaharan Africa are treated with herbicides, the same percent as on all crop lands in developed countries, while only $5 \%$ of smallholder farm acres receive herbicide applications.

\section{Crop production}

Sub-Saharan Africa has approximately 170 million hectares in agricultural production on as many small farms. Approximately one farm worker tends to crops on each hectare. Seventy percent of food production comes from these small farms, with the remainder produced on large-scale commercial plantations and government-operated ventures (Olofintoye 1987).

Current food production in sub-Saharan Africa is substantial and includes maize (43 million tons), rice (14 million tons), groundnuts ( 8 million tons), cassava (118 million tons) and sorghum (20 million tons). However, crop yields per hectare are significantly lower than global averages. Average yields obtained by smallholder farmers are considerably less

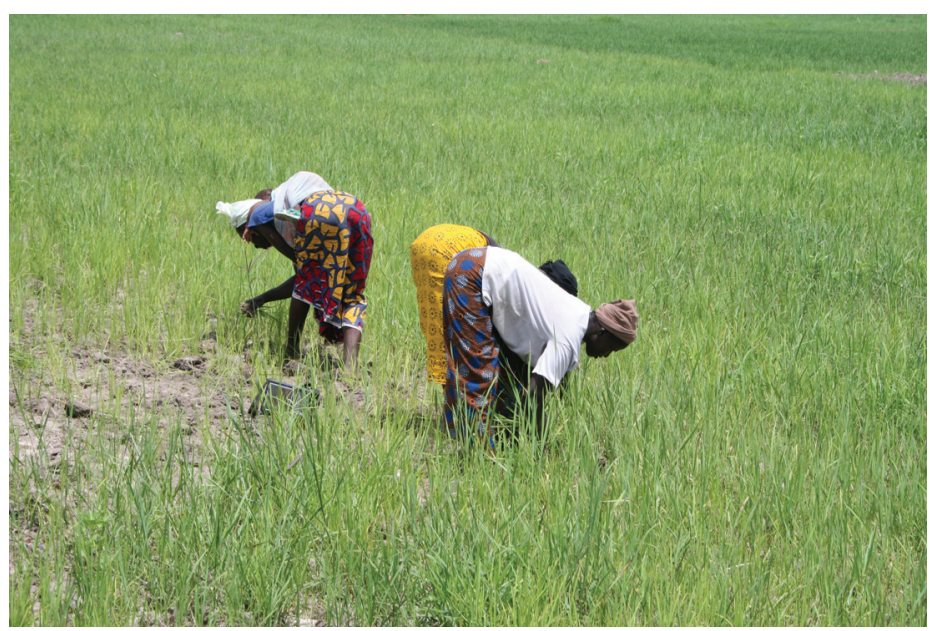

Malawian women, weeding crops than yields demonstrated in African research plots utilizing best management practices. For example, smallholder maize yields are typically 1-2 tons per hectare compared to 8 tons per hectare achieved on regional research plots (Tittonell et al. 2007; Bishop-Sambrook 2003). Rice and cassava yields are also $25 \%$ of that realized on experimental sites (DeVries \& Toenniessen 2001; Ambe et al. 1992). These substantial differences are due to the fact that researchers working in experimental plots perform farming operations, such as planting, weeding and fertilizing, at the optimal time and in the optimal amounts. Smallholder farmers are constrained in duplicating these ideal conditions. The key operation in need of improvement is the timely removal of weeds. Until weeding is improved, farmers in Africa will not realize the best yields from their crops.

\section{Weed-crop interactions}

Weeds are the most universal of all crop pests, proliferating each year on every farm in Africa. The soil seed population in a Nigerian experiment was estimated at 20,130 seeds per square meter (200 million per hectare) (Chikoye et al. 1997). A review of crop pests in sub-Saharan Africa indicated that weeds are the most important pest to control in all zones studied (Sibuga 1997). Broadleaf weeds and grasses dominate the weed spectrum, whereas sedges are minor. Weed problems are more severe in African tropical regions than in Europe and North America because weeds grow more vigorously and regenerate more quickly because of the heat and higher light intensity. High humidity and high temperature, conditions characteristic of sub-Saharan Africa, favor rapid and excessive weed growth.

Weeds reduce crop yields by competing with crops for light, water, nutrients and space. Numerous studies have documented the negative effects on yield of season-long weed competition in Africa. Under unweeded conditions, crop losses have been measured for the following: maize (55-90\%), common bean $(50 \%)$, sorghum $(40-80 \%)$, cowpea $(40-60 \%)$, rice $(50-100 \%)$, cotton $(80 \%)$, wheat $(50-80 \%)$, groundnut $(80 \%)$, and cassava $(90 \%)$ (Ambe et al. 1992; Akobundu 1987; Ishaya et al. 2007; Chikoye et al. 2004).

Weed competition is most serious when the crop is young. Weeds need to be cleared from a field prior to planting a crop and again during the growing season for optimal yields to be achieved. The critical period of weed-crop competition is approximately equal to the first one-third to one-half of the life cycle of the crop. In weed-crop competition studies, the "critical period" is the stage after which weed growth does not affect crop yields. Keeping the crop free of weeds for 
the first third of its life cycle usually assures near maximum productivity.

\section{Hand weeding}

Hand weeding is the predominant weed control practice on smallholder farms (Vissoh et al. 2004). Hand weeding is the oldest method of weed control and consists of pulling and slashing weeds by hand and hoeing. Smallholder farmers spend $50-70 \%$ of their total labor time hand weeding (Chikoye et al. 2007a). Women contribute more than $90 \%$ of the hand weeding labor for most crops (Ukekje 2004). Seven out of every 10 farm children between the ages of 5 and 14 are forced to leave school and work in the agricultural sector at the peak period of weeding (Ishaya et al. 2008).

Optimal weeding is critical to production; not only the timing of weeding but the amount is important. For example, Ishaya et al. found 309 hours were required to hand weed one hectare of maize while 324 hours of weeding were needed for one hectare of sorghum in northern Nigeria (Ishaya et al. 2007). A 1998 study of women in African agriculture confirmed that weeding took up more days in the field than any other operation (IFAD 1998). Several interviews with specialists verified that it was impossible for any one woman to keep more than a single hectare free of weeds in a typical cropping season. Before planting, 30-90 hours are required per hectare simply to remove weeds (Kienzle 2003).

Research has demonstrated the impacts of performing fewer than the optimal number of hand weedings or performing weedings at unfavorable times. With three properly spaced hand weedings, the highest cotton yields were obtained in Nigeria at $549 \mathrm{~kg} / \mathrm{ha}$; with two hand weedings, the yield was reduced by $27 \%$ to $401 \mathrm{~kg} / \mathrm{ha}$; one hand weeding resulted in a loss of $55 \%$, reducing the yield to $249 \mathrm{~kg} / \mathrm{ha}$; and total lack of hand weeding produced yields of $73 \mathrm{~kg} / \mathrm{ha}, 87 \%$ lower than optimal (Prentice 1972). However, on most farms, planting takes precedence over weeding. Poor weed management in Kenyan cassava fields caused an average yield gap of $5 \mathrm{t} / \mathrm{ha}$ in comparison to expected optimal yield; in very dry years, weeds restricted production by $11.6 \mathrm{t} / \mathrm{ha}$ (Fermont et al. 2009).

The principal limiting factor to the size of African farms is the number of necessary weedings during the period following planting (Kent et al. 2001). Johnson discovered that $80 \%$ of smallholder farmers would increase the size of their cultivated land if weeds were less of a problem (Johnson 1995). Thus, weeds can be considered the main constraint on agricultural production.

Weed infestation in crops may be so severe that weeding is not always worthwhile; therefore, fields are effectively abandoned. In Malawi, nationwide survey data reports onethird of the area planted to maize by smallholders is either left unweeded or only weeded after the critical first six weeks (Orr et al. 2002). Maize is usually the first crop to be planted and weeding becomes necessary at a time when labor is critical for planting cash crops such as groundnuts. Similarly, in Zimbabwe, $21 \%$ of cotton farmers abandon more than $20 \%$ of their crops each year as a result of weed infestation (Mavudzi et al. 2001).

Additionally, a lack of labor supply during peak weeding periods can limit the effectiveness of hand weeding. Migra- tion to urban areas, as well as the loss of healthy adults due in part to the HIV/AIDS pandemic has significantly reduced the supply of available farm labor in many countries. AIDS has caused the loss of at least $10 \%$ of the agricultural workforce in most countries and is responsible for more than a $20 \%$ loss in 5 sub-Saharan African countries (Bishop-Sambrook 2003).

The scarcity of labor and the concurrent rise in the cost of hand weeding make timely removal of weeds by direct labor difficult and expensive. African women have considerable family responsibilities, including caring for elderly parents. Each has an average of six children. Malaria, a common problem, reduces the availability of productive labor and increases the challenges of tending to a family as well as a farm. Additionally, repetitive stooping and using short-handled tools to weed can cause permanent spinal deformation. As a result of conflicting time demands and health issues, weeding is not always carried out in a timely fashion or in the right amounts. Overall, in sub-Saharan Africa, yield losses in farmers' fields range from $25 \%$ to total crop failure because farmers are unable to perform the necessary weedings at the optimal times (Vissoh et al. 2004).

\section{African weed science programs}

Weeds are an underestimated crop pest in Africa. Plant pathology and entomology take precedence over weed science. Because weeds do not strike as violently as insects, there is a tendency to underestimate their economic importance. Even when a farmer abandons a crop to weeds, such incidents do not attract attention. Weeding is still largely seen as women's work and weeds are accepted as part of the natural consequences of crop production. Because weed science research receives such a low priority, there is a lack of education in weed science at the masters and doctoral levels for scholars from sub-Saharan Africa, resulting in an absence of trained weed scientists to address the region's weed problems.

\section{Herbicides}

Herbicides are an alternative to hand weeding. Herbicides can be sprayed before planting to remove weeds from a field, applied directly to soil at planting for residual control of germinating weed seeds, and applied to weeds during the growing season. Residual herbicides applied to the soil before the crop and weeds emerge from the ground remain active in controlling germinating weed until the critical period of weed competition has passed.

In sub-Saharan Africa, herbicides have been widely adopted on large plantations of cash crops such as coffee, cotton, sugarcane, cocoa and tea. Herbicides are also widely used on large government-operated farms. Faced with rising costs and scarcity of labor for hand weeding, these plantations largely adopted herbicide technology in the 1960s and '70s (Terry 1996). Estate farmers have been able to use herbicide technology because they employ their own researchers and agronomists. In contrast, with less than $5 \%$ adoption, smallholder farmers in Africa generally do not use herbicides. In Uganda, herbicide use is extremely low at $0.1 \%$ of acres treated (Magyembe 1997). 
Experiments documenting how chemical herbicides are more cost effective and give better weed control than hand weeding include a study in which maize yields doubled and production costs fell by $61 \%$ when Nigerian farmers used atrazine (Benson 1982). In a study for groundnut production in Zimbabwe, weed control labor was reduced from an estimated 107 hours/ha to 0.4 hours/ha on plots treated with herbicides (Benson 1982). More recently, chemical control decreased costs by as much as $50 \%$ and increased yields up to $55 \%$ on Nigerian cassava, yam, and soybean plots (Chikoye et al. 2007a).

Although herbicides have been studied in weed control research and have been shown to produce greater yield at reduced cost than typical hand weeding, there has been no mechanism to disseminate information and technology to smallholder farmers (Chikoye et al. 2007b). This state of affairs is responsible for the low adoption rate. Smallholders who have adopted herbicide use tend to live near agricultural research stations or farm in cooperatives.

\section{Constraints on herbicide use}

Undoubtedly, the greatest obstacle between herbicide technology and African farmers is lack of awareness and training. Specifically, constraints involve an inadequate knowledge of which herbicide to use in a given weed-crop situation; deficiency of extension services; scarcity of trained weed science personnel; uncertainty as to the availability of herbicides; and lack of herbicides in farmer-friendly packages (Mavudzi et al. 2001).

For herbicides to be successfully introduced, several major infrastructure systems must also be improved (Benson 1982). The extension system, for example, depends on the competence of its agents, the frequency of their visits and demonstrations, and the credibility of their communications. In 1980, Dr. Akobundu identified the need for subject matter specialists capable of evaluating weed problems and formulating herbicide recommendations on a per country basis. Farmers in sub-Saharan Africa are still operating without this expertise. Transportation and distribution of herbicides needs to be more reliable, as farmers must apply them on time in order for them to be useful. Farmers also need access to inexpensive credit and their products must be transported to market quickly and sold at a fair price.

Efforts must be made to enlighten governments on the role of weed science in the crop production equation, so as to bring governments to bear on the need for plans of action to address the problem. Although there are many U.S. funded agricultural development projects in Africa with several U.S. universities as contracting institutions, hardly any of the projects have included training in weed science.

\section{Fertilizer usage potential}

Increased use of fertilizer has been promoted for several decades as a way of significantly increasing yields in the region. At the African Fertilizer Summit of 2006, the African Union member states set a goal of increasing fertilizer use by $500 \%$ by 2015 (IFDC 2007). Fertilizer tends to be used mainly on cash crops and plantation crops. However, the benefits of fertilizer depend on weed control. Applying fertilizer competes for labor with weeding and planting of additional crops. As a result, fertilization is often done at the wrong time. Crops may not respond to fertilizer applied late (Makanganise et al. 1999).

Additionally, since hand weeding can only be done once the weeds are large enough to be seen and effectively pulled, fertilization allows weeds to absorb fertilizer that would otherwise be available for the crop. Many weeds absorb nutrients more efficiently than crops. For example, fertilization of weedy maize plots actually increased yield losses caused by weeds by $62 \%$ in a South African trial (Benson 1982). Without weed control, increased fertilization simply leads to more weeds with the subsequent need for more labor to pull them. African farmers are reluctant to use greater amounts of fertilizer until the weed problem is brought under control.

\section{Potential impacts of herbicide use}

By reducing the labor required for weed control, herbicide use could allow additional resources to be invested in food crops to the benefit of food security in the region (Mavudzi et al. 2001). Along with food security and better nutrition, the potential benefits of herbicide use include increased incomes and reduced drudgery. These benefits are particularly salient to women, children and the poor. A social benefit occurs when children are able to attend school because they are not needed to weed fields. Herbicide use would also release women from the toil of weeding, preventing chronic pain and spinal deformation while enabling them to pursue goals such as education or small business entrepreneurship.

The economic benefits of herbicides can be realized if the hired labor released from hand weeding is gainfully employed elsewhere. There is ample work in other crops that is often delayed or neglected due to lack of labor. In some crops, such as cotton and groundnuts, there is much work other than weeding that requires hand labor. Likewise, increasing the area that is harvested through improved weed control will provide more employment opportunities for hired labor during the harvest (Mavudzi et al. 2001). Using herbicides in groundnut production could save up to three weeks of time, allowing attention to other tasks, such as substantially increasing the area planted (Schilling 2003). It is this use of time that is of prime importance to the African farmer. If the farmer can use time saved from manual weeding to carry out other profitable operations, then there is a good case for using herbicides (Benson 1982).

A 2009 assessment by the National Academy of Sciences identified lightweight herbicide sprayers as a technology that would transform agriculture in the region (NRC 2009). The report noted that a woman can farm twice the area and realize greater yields with an herbicide sprayer than with hand weeding. In a 2002 Kenyan research trial, herbicides increased net benefits by $61 \%$ in a maize/bean intercrop and $46 \%$ in a maize monocrop (Kibata et al. 2002).

If a reliable source of herbicides and trained applicators were available, smallholder farmers in Africa would adopt herbicide technology. For example, as a result of a training program for applicators in Zambia, so many farmers 
requested spraying that the supply of herbicides in the country was exhausted two years in a row (Ngoma 2010).

\section{Summary}

Approximately $75 \%$ of the 250 million tons of crops grown in sub-Saharan Africa is produced on smallholder farms. Three-quarters of these farms are weeded by hand. Weed infestations and re-infestations are heavy and rapid, allowing no breathing space for the African farmer. Even if other inputs such as fertilizer and improved seeds are available, agricultural outputs will remain at the subsistence level as long as the hand-hoe is the primary means of weeding (IFAD 1998).

Herbicides have great potential for solving the weed problem in Africa. Herbicides reduce the need for labor during planting time and they are less expensive than hiring labor for weeding. Herbicide use would improve the lives of women and children by eliminating dangerous work that can lead to permanent deformities.

Herbicides are used on more than $90 \%$ of the cropland in the United States, the European Union, Japan, and Australia, as well as on large-scale commercial farms in Africa. It is the smallholder African farmer that is still unable to benefit from herbicide technology. Although African agriculture faces many challenges, including a lack of farmer education and chemical training, unreliable water supply on many farms, and insufficient infrastructure, we estimate $25 \%$ of smallholder farmers could use herbicide technology now to their benefit. If given the opportunity, these farmers are likely to adopt this technology as their counterparts have all over the world.

\section{References}

Akobundu, I.O. 1987. Weed Science in the Tropics: Principles and Practices, Chichester: A Wiley-Interscience Publication.

Akobundu, I.O. 1991. Weeds in human affairs in sub-Saharan Africa: implications for sustainable food production, Weed Technology, 5, pp 680-90.

Ambe, J.T., A.A. Agboola, \& S.K. Hahn. 1992. Studies of weeding frequency in cassava in Cameroon, Tropical Pest Management, 38(3), pp 302-4.

Benson, J.M. 1982. Weeds in Tropical Crops: Review of Abstracts on Constraints in Production Caused by Weeds in Maize, Rice, Sorghum-millet, Groundnuts and Cassava. FAO Plant Production and Protection Paper, 32(1).

Bishop-Sambrook, C. 2003. Labour Saving Technologies and Practices for Farming and Household Activities in Eastern and Southern Africa, IFAD \& FAO.

Chikoye, D., F. Ekeleme, \& I.O. Akobundu. 1997. Weed composition and population dynamics in intensified smallholder farms in West Africa, The 1997 Brighton Crop Protection Conference, Weeds.

Chikoye, D., J. Ellis-Jones, C. Riches, \& L. Kanyomeka. 2007a. Weed management in Africa: experiences, challenges and opportunities, XVI International Plant Congress, pp 652-3.

Chikoye, D., S. Schultz, \& F. Ekeleme. 2004. Evaluation of integrated weed management practices for maize in the northern Guinea savanna of Nigeria, Crop Protection, 23, pp 895-900.

Chikoye, D., U.E. Udensi, A.F. Lum, \& F. Ekeleme. 2007b. Rimsulfuron for post emergence weed control in corn in humid tropical environments of Nigeria, Weed Technology, 21, pp 977-81.

DeVries, J. \& G. Toenniessen. 2001. Securing the Harvest: Biotechnology, Breeding and Seed Systems for African Crops, The Rockefeller Foundation, New York.

Fermont, A.M., P.J.A. van Asten, P. Tittonell, M.T. van Wijk, \& K.E. Giller. 2009. Closing the cassava yield gap: an analysis from smallholder farms in East Africa, Field Crops Research, 112, pp 24-36.

IFAD. 1998. Agricultural Implements Used by Women Farmers in Africa, Rome.

IFDC. 2007. Africa Fertilizer Summit Proceedings, IFDC Publications.

Ishaya, D.B., P. Tunku, \& N.C. Kuchinda. 2008. Evaluation of some weed control treatments for long season weed control in maize under zero and minimum tillage at Samaru in Nigeria, Crop Protection, 27, pp 1047-51.

Ishaya, D.B., S.A. Dadari, \& J.A.Y. Shebayan. 2007. Evaluation of herbicides for weed control in sorghum (Sorghum bicolour) in Nigeria, Crop Protection, 26, pp 1697-1701.

Johnson, D.E. 1995. Weed management strategies for smallholder rice production, The 1995 Brighton Crop Protection Conference, Weeds, pp 1171-80.

Kent, R., D.E. Johnson, \& M. Becker. 2001. the influences of cropping system on weed communities of rice in Cote d'Ivoire, West Africa, Agriculture, Ecosystems and Environment, 87, pp. 299-307.

Kibata, G.N., J.M. Maina, E.G. Thuranira, F.J. Musembi, G. Nyanya, J.G.N. Muthamia, J.O. Okuro, I. Mutura, S. Amboga, A.N. Micheni, F. Mureithi, D. Overfield, \& P.J. Terry. 2002. Participatory development of weed management strategies in maize based cropping systems in Kenya, Thirteenth Australian Weeds Conference, 343-4.

Kienzle, J. 2003. Labour Saving Technologies and Practices for Farming and Household Activities in Eastern and Southern Africa, Agricultural and Food Engineering Technologies Service. FAO, paper presented at HIV AND AIDS Mitigation Workshop, Pretoria, South Africa.

Magyembe, J.M. 1997. Herbicide use in Uganda, $16^{\text {th }}$ East African Biennial Weed Science Conference Proceedings, pp 165-169.

Makanganise, A., S. Mabasa, L. Jasi, \& E. Mangosho. 1999. Farmer participation and evaluation of their preceptions on integrated weed control methods with specific reference to herbicide technology in communal areas of Zimbabwe, 17 th East African Biennial Weed Science Conference Proceedings, pp 97-107.

Mavudzi, Z., A.B. Mashingaidze, O.A. Chivinge, J. Ellis-Jones, \& C. Riches. 2001. Improving weed management in a cotton-maize system in the Zambezi Valley, Zimbabwe, The 2001 Brighton Crop Protection Conference, Weeds, pp 169-74.

Ngoma, P. 2010. Success Story - Training: Spray Service Providers' Programme, CropLife Zambia, Hub Meeting East and Southern Africa, 24-25 August 2010, Dar-es-Salaam, Tanzania.

NRC. 2009. Emerging Technologies to Benefit Farmers in Sub-Saharan Africa and South Asia, National Academies Press, Washington, DC.

Olofintoye, J.A. 1987. Effects of tillage and weed control methods on weed growth and performance of upland rice in the Guinea savanna of Nigeria, Nigerian Journal of Agronomy, 2(3), $82-7$.

Orr, A., B. Mwale, \& D. Saiti. 2002. Modeling agricultural 'performance': smallholder weed management in southern Malawi, International Journal of Pest Management, 48(4), pp 265-78.

Prentice, A.N. 1972. Cotton with Special Reference to Africa, Longman, London.

Schilling, R. 2003. Groundnut, The Tropical Agriculturalist, MacMillan. 
Sibuga, K.P. 1997. Weed management in Eastern and Southern Africa: challenged for the 21st century. $16^{\text {th }}$ East African Biennial Weed Science Conference Proceedings, pp 5-11.

Terry, P.J. 1996. The use of herbicides in the agriculture of developing countries, Second International Weed Control Congress, pp 601-9.

Tittonell, P., M.T. van Wijk, M.C. Rufino, J.A. Vrugt, \& K.E. Giller. 2007. Analysing tradeoffs in resource and labour allocation by smallholder farmers using inverse modeling techniques: a casestudy from Kakamega district, western Kenya, Agricultural Systems, 95, pp 76-95.

Ukekje, E. 2004. Modernizing Small-holder Agriculture to Ensure Food Security and Gender Empowerment: Issues and Policy, Intergovernmental Group of Twenty Four, http://www.g24.org/ researchpapers.html

Vissoh, P.V., G. Gbehounou, A. Ahanchede, T.W. Kuyper, \& N.G. Roling. 2004. Weeds as agricultural constraint to farmers in Benin: results of a diagnostic study, NJAS, 52(3/4), pp 305-29.
Leonard Gianessi has served as Director of the Crop Protection Research Institute, the research and education institute of CropLife Foundation, since January 2004. Leonard has focused the research efforts of CPRI on the examination of pesticide use, regulation, and policy with an emphasis on quantifying the benefits of and continued need for pesticide use in U.S agriculture. He has authored comprehensive reports on the benefits of using herbicides, fungicides and insecticides in US crop production. Prior to joining the CropLife Foundation, Leonard was a Senior Research Associate at the National Center for Food and Agricultural policy where he led studies of the potential impacts of biotechnology on US and European crop production. Leonard began his professional career with a 17-year appointment at Resources for the Future where he specialized in the development of databases for studies of air and water pollution and pesticide use. Leonard has testified before Congressional Committees regarding pesticide policies in four hearings. Leonard has a BA in public affairs from George Washington University.

Ashley Williams is the research assistant at CropLife Foundation. She is completing her Master's of Public Health in Environmental and Occupational Health at George Washington University. Her professional interests include water scarcity issues, waste water management, and the public health concerns surrounding agriculture in developing countries, a newfound interest inspired by working at CropLife. Ashley holds a BA in Anthropology from Indiana University.

\section{Similar articles that appeared in Outlooks on Pest Management include - 2002 I3(5) 197;} $200920(2) 77$

\section{Future articles in Outlooks on Pest Management will include -}

Pesticides and bee health

- Biopesticide use and research in Brazil

- Status of alternatives for methyl bromide in the United States

- Sunn pest in Afghanistan

- Bt maize and IPM in Europe

- The pros and cons of using irradiation for phytosanitary treatments

- The development of insect repellents

- An emerging mouse plague developing in southern Australia

- Collection of pesticide containers

- The molecular basis of resistance to SDHI fungicides

- The benefits of plant breeding

- IP and saved seed in Europe

- Why are there not more GM crops?

- The Waste Directive

- The resurgence of mirid bugs on Bt cotton in China and how this is being tackled

- California's efforts to reduce pest problems through control at borders

- Non-target or secondary effects of fungicides
- Fungicide resistance in Brazil

- Insecticide discovery in the post-genomic era

- The SCARDA programme and its impact on African agriculture

- Opportunities for non-food crops in today's farming systems

- Controlling potato cyst nematode in potato crops with a fungus

- Pesticide container disposal from US and International perspectives

- Counterfeiting and other illegal PPPs

- The abuse of the parallel trade rules for the supply and distribution of illegal/unregistered PPPs across Europe

- Insecticide Toxicology with particular reference to cotton ecosystems

- The changing face of farm economics in Europe

- Why industry needs IPM/ICM

- Opportunities and Initiatives to minimise children's exposures to pesticides

- Economics of insect pathogens used for insect management 